\title{
Genetic Diversity and Population Structure of Endangered Indian Catfish, Clarias magur as Revealed by mtDNA D-loop Marker
}

\author{
Lakshman Sahoo ${ }^{1, *}{ }^{-}$, Ashoktaru Barat ${ }^{1}$, Sangram Ketan Sahoo ${ }^{1}$, Bismay Sahoo, \\ Gargee Das ${ }^{1}$, Paramananda Das, Jitendra Kumar Sundaray ${ }^{1}$, Saroj Kumar Swain ${ }^{1}$
}

${ }^{1}$ Central Institute of Freshwater Aquaculture, Kausalyaganga, Bhubaneswar-751002, India.

\section{Article History}

Received 03 July 2020

Accepted 10 November 2020

First Online 12 November 2020

\section{Corresponding Author}

Tel.: +916742465421

E-mail: lakshmansahoo@gmail.com

\section{Keywords}

Genetic Diversity

Genetic Differentiation

Private Allele

Haplotype Diversity

Nucleotide Diversity

\begin{abstract}
Clarias magur, popularly known as magur, is one of the economically important catfish species having high aquaculture potential in India due to its efficient food conversion, taste, and nutritional benefits. Due to habitat degradation, over exploitation, lack of resources, indiscriminate use of agricultural pesticides and introduction of competitor exotic species, the wild populations are dwindling day by day. According to IUCN, it is listed as endangered species. In the present study, the population genetic structure of 206 magur samples collected from seven different geographical regions was examined using partial mitochondrial D-loop (control region) sequence variation. In total of 17 haplotypes were observed with high number of private alleles, number of haplotypes ranged from 2 to 6 and maximum number of haplotypes was observed in UP population. Haplotype diversity and nucleotide diversity ranged from 0.06897 to 0.76322 and 0.00019 to 0.00208 , respectively. Pairwise $F_{S T}$ values ranged from 0.01383 to 0.62069 and highest genetic differentiation was observed between AP and AS population. Low genetic diversity and significant population genetic differentiation was observed in the present study. The information generated in the present investigation would facilitate formulating appropriate strategy for management, conservation, and genetic improvement program of this commercially important aquaculture species.
\end{abstract}

\section{Introduction}

The family Clariidae consisted of 16 genera and 116 species (https://www.fishbase.se) out of 16 genera the genus Clarias alone consisted of 57 species (Ferraris, 2007). The Indian catfish, Clarias magur is popularly known as magur and is widely preferred in South East Asian countries due to certain characteristics such as nutritional and medicinal values and flesh quality (Majhi et al. 2020). Magur is a facultative air-breather, commercially important freshwater fish having enormous potential as candidate aquaculture species in India and adjacent countries due to its high growth rate and efficient food conversion (Roy et al., 2019). Magurs are naturally inhabitants of stagnant, slow flowing, swampy and muddy water bodies often characterized by low oxygen content, high carbon and ammonia. Magur in wild is distributed in Ganga and Brahmaputra river basins of North and Northeast India, Nepal, Bhutan and Bangladesh ( $\mathrm{Ng}$ and Kottelat, 2008; Vishwanath, 2010). As per the reports of International Union for Conservation of Nature (IUCN), the natural populations of $C$. magur has declined in its natural range and it has become endangered species (Vishwanath, 2010). Several factors such as over exploitation, climate change, pollution, excessive use of pesticides, herbicides and inorganic fertilizers in agricultural farms, devastation of natural habitat and unregulated introduction of alien species such as African catfish (Clarias gariepinius), a competitor of $C$. magur for food 
and habitat are responsible for dwindling of wild populations (Banerjee et al., 2019; Roy et al., 2019). Therefore, appropriate conservation strategies need to be developed and implemented for sustainable production and preservation of natural gene pool of this economical important species. Clear understanding of gene flow, population genetic differentiation and identification of genetically discrete populations are essential requirements for effective implementation of conservation strategies (Melis et al., 2018). Identification of genetically distinct populations, quantification of genetic connectivity and assessment of gene flow depends on availability of genetic data (Ovenden et al., 2016).

Invariably, molecular genetic markers were used for estimation of population genetic parameters in plants and animals including fish (Han et al., 2012; Hong et al., 2012; Gong et al., 2018; Souza-Shibatta et al., 2018). Polymerase chain reaction (PCR) based DNA markers are advantageous and have been successfully employed for estimation of within and between population genetic diversity of several aquaculture species (Liu and Cordes, 2004). Mitochondrial DNA markers are cost effective and easy to develop in comparison to microsatellite and single nucleotide polymorphism (SNP) markers and can be used efficiently for estimation of population genetic parameters (Quilang et al., 2007; Fleury et al., 2009). Mitochondrial DNA markers have been widely employed for ecological studies, estimating genetic diversity indices, population genetic characterization, phylogenetics, genetic introgression and species and hybrid identification (Avise et al., 1986; Ferguson et al., 1995).

High mutational rate, small size, maternal inheritance and single locus nature of mtDNA sequences make them extremely suitable for examining fine population structure and other ecological studies (Liu and Cordes, 2004; Galtier et al., 2006). Numerous mtDNA regions such as control region, ATPase 6/8, COI, Cyt $b$ and 16s RNA have been employed for population genetic characterization of several fish species (Swain et al., 2014; Chan et al., 2016; Langille et al., 2016; Das et al., 2017a, b). Existence of genetic diversity in a species is essential for ecosystem restoration, and its ability to react to environmental changes (Lynch and Conery, 2003; Reed, 2004; Reusch et al., 2005; Zhang et al., 2020). Several factors such as population structure, population bottlenecks, natural selection, life cycles, and mating systems shapes the genetic diversity of a species (Cherry and Wakeley, 2003; Hoban et al., 2016). Genetic diversity is essential for long term existence and genetic improvement of any species. Nevertheless, the molecular genetic data available for an aquaculture important species like magur is not comprehensive. Few population genetic studies have been undertaken to examine the genetic structure of Indian magur populations (Khedkar et al., 2010; Khedkar et al., 2016; Jousy et al., 2017; Tiknaik et al., 2020). However, none of the studies encompasses magur populations across
India. Therefore, our aim is to further explore the genetic back ground of $C$. magur populations. We have analyzed the population genetic structure of magur originating from seven wild populations, specifically from Eastern, North-Eastern, Northern and parts of Southern India utilizing partial D-loop (control region) sequences of mitochondrial DNA. The result of the present study will facilitate to formulate appropriate conservation strategy and sustainable production of this commercially important species.

\section{Materials and Methods}

\section{Sample Collection and Sequencing}

The Indian Catfish C. magur is widely distributed in India. In the present study, prime importance was given to collect wild populations not included in the previous studies and magur samples were collected with the help of local fishermen and/or from local fish market. All handling of fish was carried out following the guidelines for control and supervision of experiments on animals by the Government of India and approved by Institutional Animal Ethics Committee (AEC) of ICARCIFA. A total of 206 magur specimens from seven different geographical regions Vijayawada, Andhra Pradesh (AP), Bhubaneswar, Odisha (OD), Guwahati, Assam (AS), Raipur, Chhattisgarh (CG), Kolkata, West Bengal (WB), Patna, Bihar (BR) and Varanasi, Uttar Pradesh (UP)) of India (Figure 1 and Table 1) were sampled. Fin tissues were collected and preserved in 95 $\%$ ethanol at $-20^{\circ} \mathrm{C}$ till further use. High molecular weight gDNA was extracted using standard phenol-chloroform method (Sambrook et al., 1989). A pair of species specific primer encompassing the variable region of $D$ loop (CR) was designed from the complete mtDNA sequence available in the NCBI database. Partial D-loop region of Clarias magur was amplified with designed primers (Forward F: 5'-CTTCCTAGCGCCAGAAAAGA-3' and Reverse R1: 5'- TCAATCGAGCCTTACCTGGTTG-3'). Polymerase chain reaction was performed in $25 \mu \mathrm{l}$ reaction volume containing $2.5 \mu$ l of 10 X PCR buffer, 200 $\mu \mathrm{M}$ of dNTP mix, $1 \mu \mathrm{l}$ (10 pmol) of each primer, $2 \mu \mathrm{l}$ $(25 \mathrm{ng} / \mu \mathrm{l})$ of template DNA and $0.25 \mathrm{U}$ of Taq DNA polymerase. The PCR was performed on a GenAmp PCR System (Applied Biosystems Inc., Foster City, CA, USA) with initial denaturation for $5 \mathrm{~min}$ at $94^{\circ} \mathrm{C}$ followed by 35 cycles with following conditions: $\left(1 \mathrm{~min}\right.$ at $94^{\circ} \mathrm{C}, 1 \mathrm{~min}$ at $62^{\circ} \mathrm{C}$, and $1 \mathrm{~min}$ at $72^{\circ} \mathrm{C}$ ), with final extension at $72^{\circ} \mathrm{C}$ for $10 \mathrm{~min}$. The PCR product was visualized on $1.5 \%$ agarose gel and purified using Qiagen PCR purification kit followed by bidirectional cycle sequencing on $A B I$ 3100 PE automated capillary sequencer.

\section{Data Analysis}

Raw sequences were manually checked using the program BioEdit (Hall, 1999) and multiple sequence alignment was performed using the program ClustalW 
as implemented in MEGAX (Kumar et al. 2018). The multiple sequence alignments were manually checked and level of intra-population genetic diversity were estimated based on indices of haplotype diversity ( $h$ ) (Nei and Tajima, 1983) and nucleotide diversity $(\pi)$ (Jukes and Cantor, 1969) in DnaSP version 6 (Rozas et al., 2017). Analysis of molecular variance was performed to examine genetic diversity of $C$. magur using Arlequin version 3.5 (Excoffier and Lischer, 2010). Pair wise fixation index (Fst) for all population pairs was computed using the program Arlequin version 3.5 to assess the levels of geographically structuring of the genetic variability. The program PopART was used to generate a median joining network to examine the genealogical relationship among D-loop haplotypes. The haplotype distribution was represented in the map as well. Further, a maximum likelihood based phylogenetic tree was constructed using the program MEGA X using $\mathrm{HKY}+\mathrm{I}$ model with 1000 bootstraps by taking Labeo rohita as an out group.

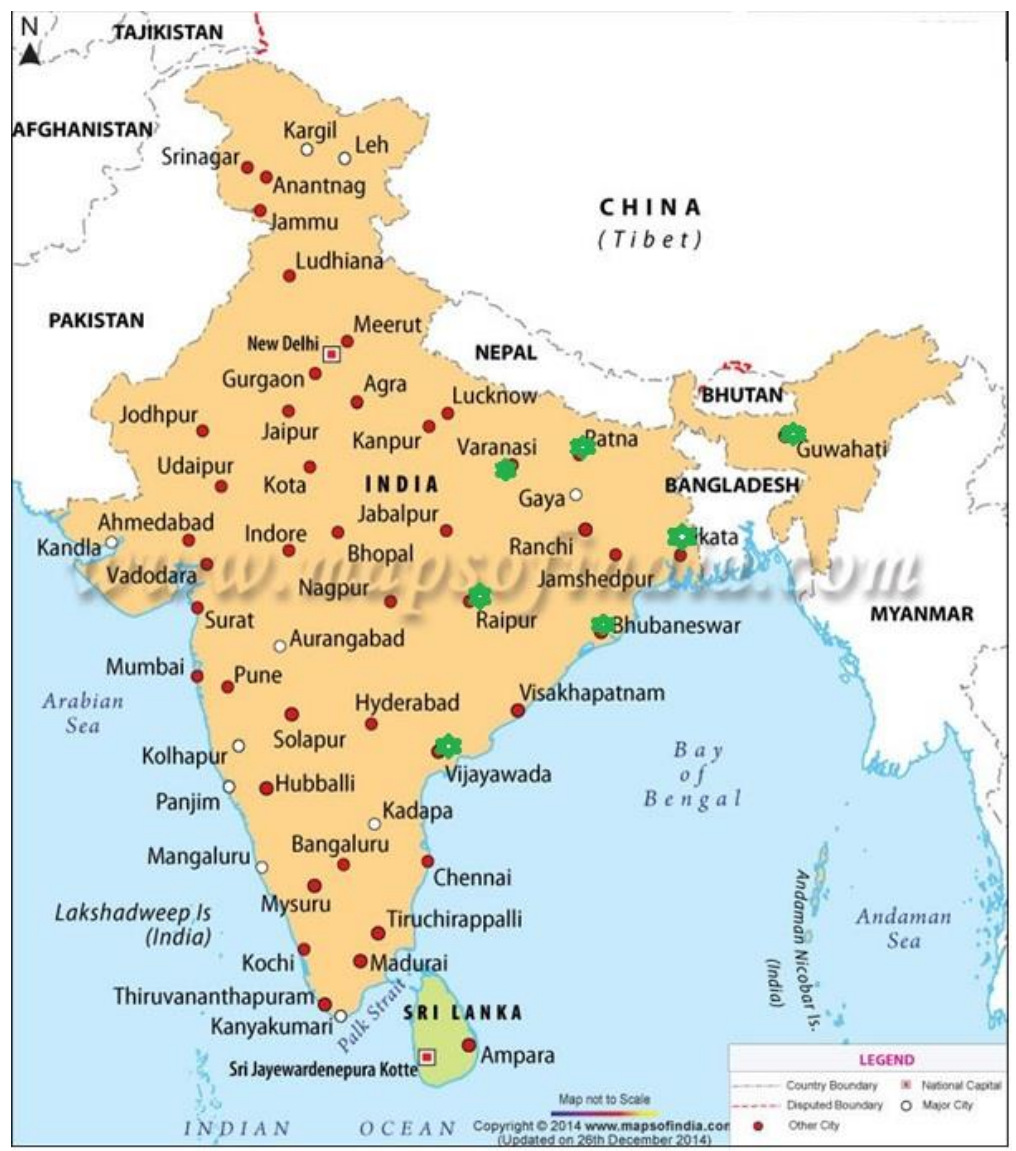

Figure 1. Different Clarias magur sampling site. Sites of sample collection.

Table 1. Number of individuals, haplotype number, haplotype diversity and nucleotide diversity, Tajima's ' $D$ ' Fu's ' $F$ ', Raggedness index ' $r$ ' and Square of Standard Deviation (SSD) of Clarias magur populations

\begin{tabular}{|c|c|c|c|c|c|c|c|c|c|}
\hline Population & Code & $\begin{array}{l}\text { Number of } \\
\text { Individuals }\end{array}$ & $\begin{array}{l}\text { Number of } \\
\text { Haplotypes }\end{array}$ & $\begin{array}{l}\text { Haplotype } \\
\text { Diversity }\end{array}$ & $\begin{array}{l}\text { Nucleotide } \\
\text { Diversity }\end{array}$ & $\begin{array}{c}\text { Tajima's } \\
D\end{array}$ & $\begin{array}{c}\text { Fu's } F \\
\quad F\end{array}$ & $\begin{array}{c}\text { Raggedness } \\
\text { index } \\
r\end{array}$ & $\begin{array}{l}\text { Square of } \\
\text { Standard } \\
\text { Deviation } \\
\text { (SSD) }\end{array}$ \\
\hline $\begin{array}{l}\text { Vijayawada, } \\
\text { Andhra Pradesh }\end{array}$ & AP & 30 & 02 & 0.129 & 0.00018 & -0.76373 & $\begin{array}{c}- \\
0.43926\end{array}$ & $0.567(0.370)$ & $0.040(0.16)$ \\
\hline $\begin{array}{l}\text { Bhubaneswar, } \\
\text { Odisha }\end{array}$ & OD & 29 & 02 & 0.069 & 0.00030 & -1.73263 & 0.169 & $0.876(0.850)$ & $0.00(0.120)$ \\
\hline $\begin{array}{l}\text { Guwahati, } \\
\text { Assam }\end{array}$ & AS & 30 & 05 & 0.457 & 0.00126 & -1.19035 & -0.957 & $0.309(0.960)$ & $0.313(0.00)$ \\
\hline $\begin{array}{l}\text { Raipur, } \\
\text { Chhattisgarh }\end{array}$ & CG & 27 & 03 & 0.382 & 0.00095 & -0.34809 & 0.577 & $0.310(0.370)$ & $0.035(0.24)$ \\
\hline $\begin{array}{l}\text { Kolkata, } \\
\text { West Bengal }\end{array}$ & WB & 30 & 04 & 0.697 & 0.00131 & 0.48288 & 0.181 & $0.147(0.06)$ & $0.013(0.210)$ \\
\hline $\begin{array}{l}\text { Patna, } \\
\text { Bihar }\end{array}$ & $B R$ & 30 & 05 & 0.630 & 0.00114 & 0.10425 & -1.247 & $0.149(0.06)$ & $0.016(0.150)$ \\
\hline $\begin{array}{l}\text { Varanasi, } \\
\text { Uttar Pradesh }\end{array}$ & UP & 30 & 06 & 0.763 & 0.00206 & 0.37760 & -0.581 & $0.043(0.73)$ & $0.001(0.77)$ \\
\hline
\end{tabular}

*Figures in parenthesis depicts the $P$-values 
Arlequin version 3.5 was used to perform mismatch and neutrality tests. In order to evaluate the population expansion, Tajima's D test (Tajima, 1989) and Fu's Fs test (Fu, 1997) were chosen to examine the deviations from neutrality. Additionally, Harpending's raggedness index (Harpending et al., 1994) and the sum of squared deviations (SSD) between the observed and expected mismatch for each of the populations were calculated using the methods of Schneider and Excoffier (1999) using Arlequin version 3.5 to examine the population demographic changes using a parametric bootstrap approach (500 replicates). The smoothness of the observed mismatch distribution was measured by this method and a non-significant result implies an expanding population (Harpending, 1994).

\section{Results}

\section{Sequence Composition and Genetic Diversity}

Partial D-loop/CR sequence of $699 \mathrm{bp}$ length from 206 individuals were sequenced and submitted in the NCBI GenBank (Accession number MT376381 MT376586). In total 16 variable sites were observed consisting of 15 parsimonious informative sites and one singleton variable site. Examination of average nucleotide composition of four nucleotide bases revealed $A T$ bias ( $T=32.3 \%, A=33.0 \% C=21.7 \%$, and $G$ $=12.9 \%)$. In the present investigation, 17 mitochondrial haplotypes were observed, number of haplotypes ranged from 2 to 6 and maximum number of haplotypes was observed in UP population (6 haplotypes) (Table 1 ).
The haplotype Hap01 was shared by all the populations in addition to this population specific haplotypes were observed in the present study. Haplotype frequencies of different populations are depicted in Figure 2. The haplotype diversity $(\mathrm{Hd})$ and nucleotide diversity (Pi) ranged from 0.06897 to 0.76322 and 0.00019 to 0.00208 , respectively (Table 1 ). The median joining network of haplotypes revealed Hap01 is related to all other haplotypes suggesting it to be the ancestral one and the haplotype distribution was depicted on the map (Figure 3).

\section{Genetic Differentiation}

In the present study, within population variation was observed to be $65.99 \%$ and among population variation was observed to be $34.01 \%$ as revealed by analysis of molecular variance (AMOVA) (Table 2). Pair wise $F_{S T}$ analysis revealed highly significant genetic differentiation among magur populations. Pair wise FST varied from 0.01383 to 0.62069 and highest genetic differentiation was observed between AP and AS population (Table 3). The average Fst in the present investigation was found to be 0.34014 . To examine the relationships and divergence of magur haplotypes a likelihood based phylogenetic analysis was performed and strongly supports the monophyly of $C$. magur (Figure 4). This revealed the presence of one group of $C$. magur in India.

Table 1 represented the values of neutrality test, including Tajima's D and Fu's Fs analysis. In all populations negative values were observed. However,

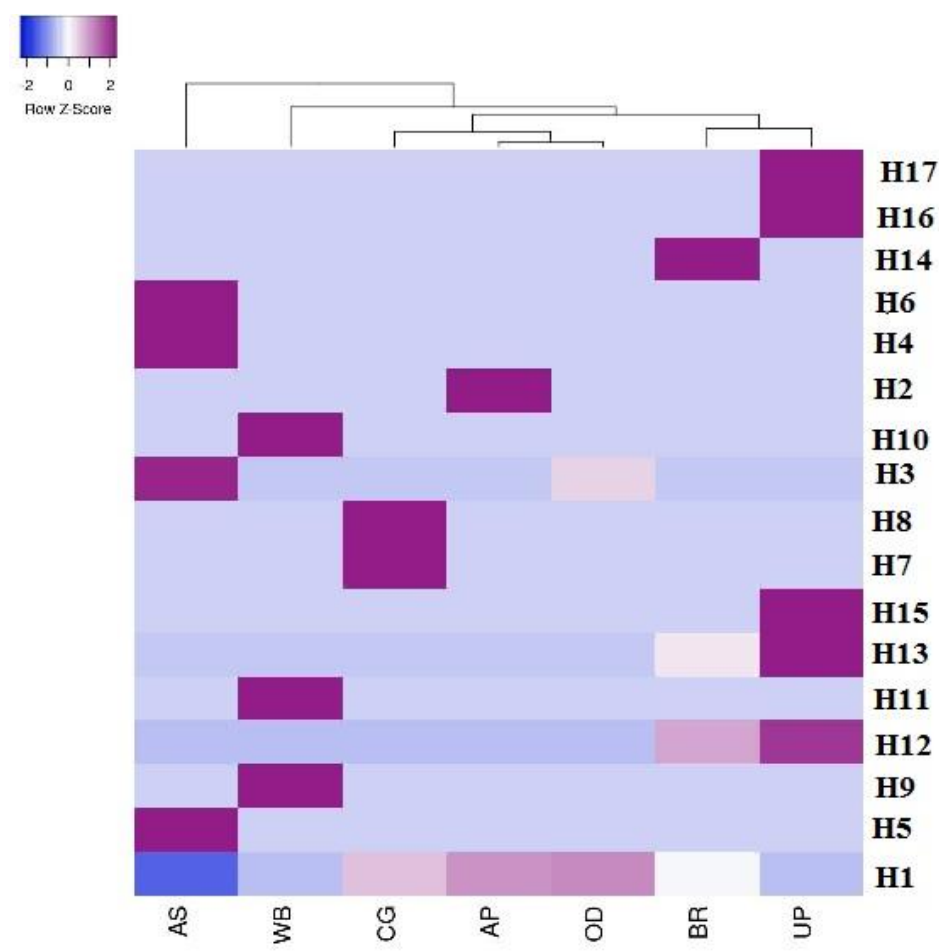

Figure 2. Heatmap of Clarias magur D-loop haplotype frequencies. 


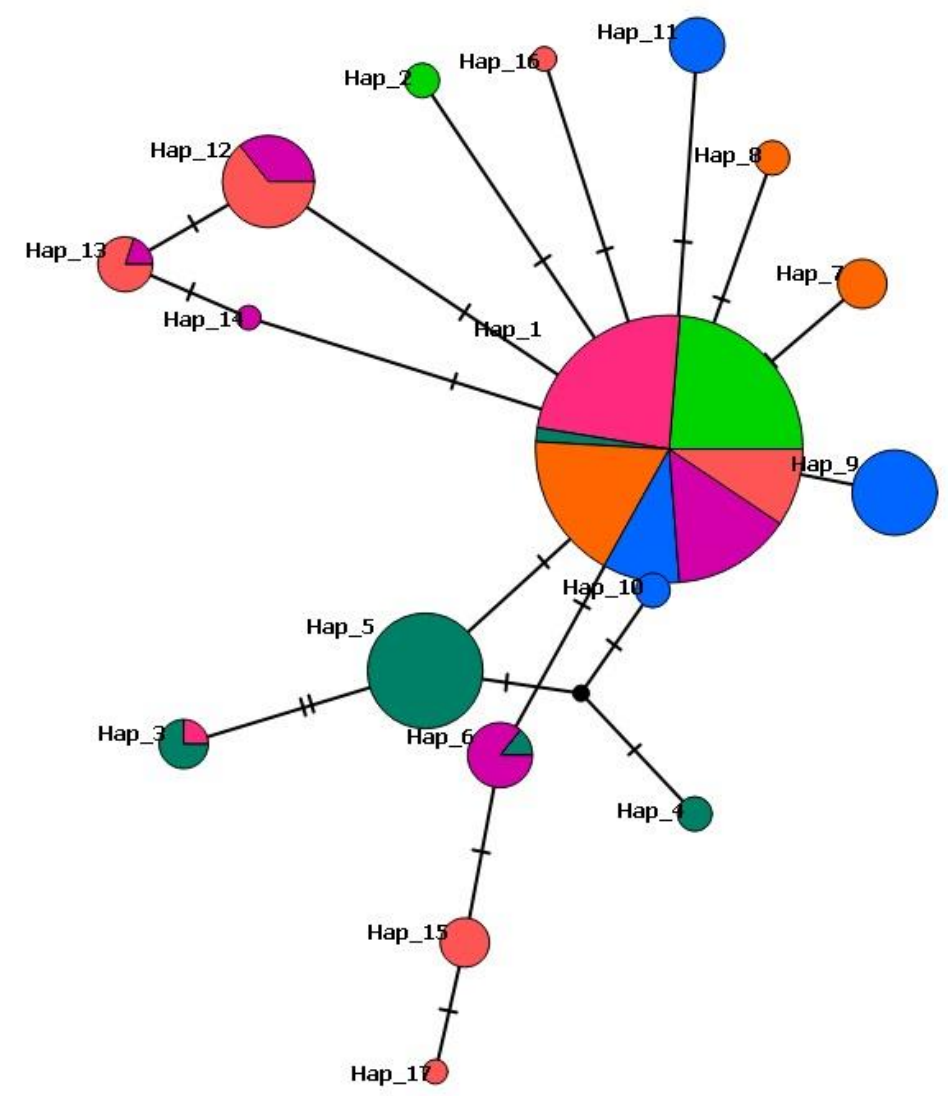

Figure 3. A) Median joining network of Clarias magur D-loop haplotypes.

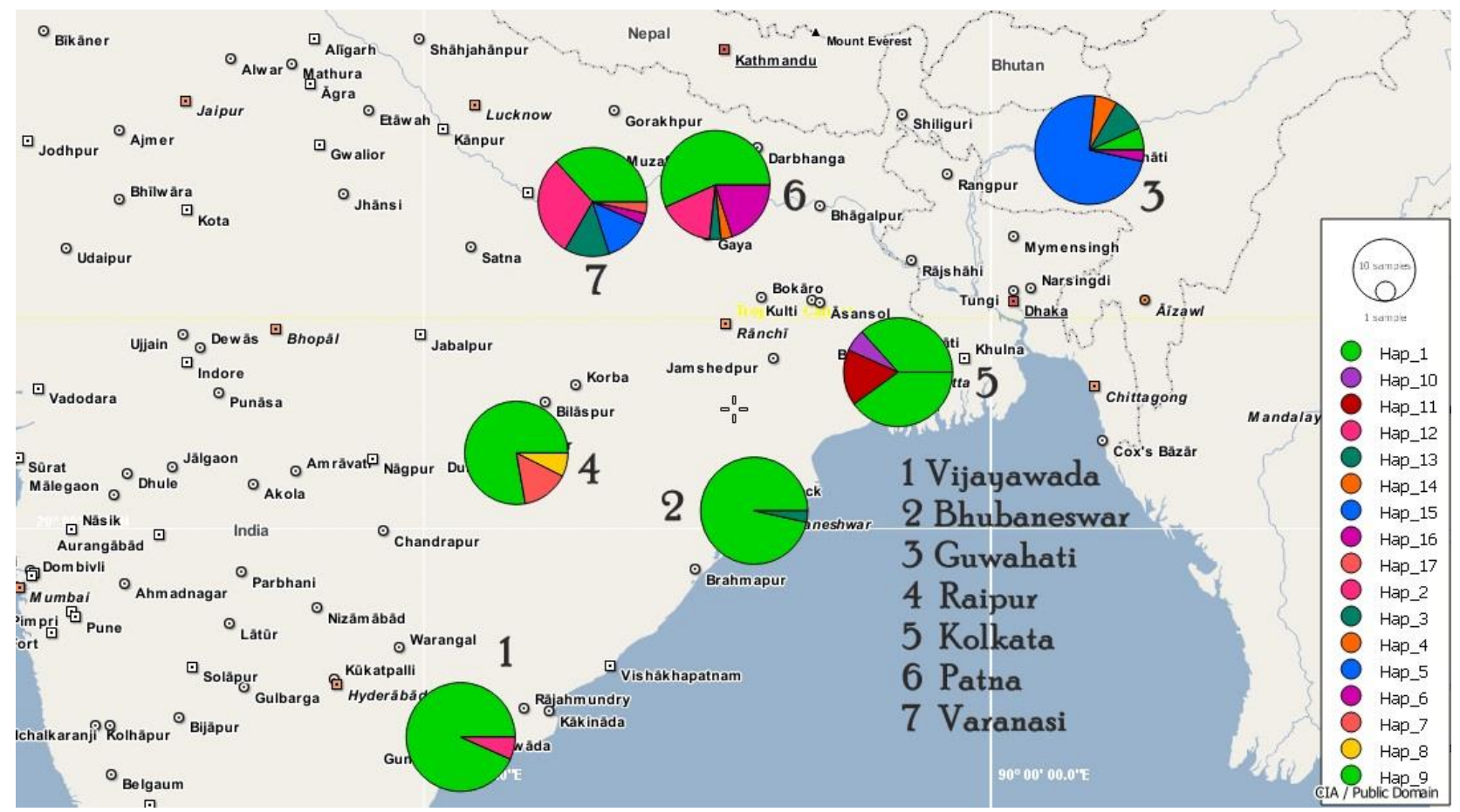

Figure 3. B) Distribution of haplotypes in sampling locations. 
Table 2. Analysis of molecular variance of Clarias magur population

\begin{tabular}{lcccc}
\hline Source of variation & d.f & Sum of squares & Variance components & Percentage of variation \\
\hline Among populations & 6 & 34.980 & $0.18589 \mathrm{Va}$ & 34.01 \\
Within populations & 199 & 71.763 & $0.36062 \mathrm{Vb}$ & 65.99 \\
Total & 205 & 106.743 & 0.54651 & 100 \\
\hline
\end{tabular}

Table 3. Pair wise $\mathrm{F}_{\mathrm{ST}}$ among seven Clarias magur populations

\begin{tabular}{lccccc}
\hline \multicolumn{1}{l}{ Pabulation } & AP & OD & AS & CG & WB \\
\hline AP & 0.00000 & & & & \\
OD & 0.01383 & 0.00000 & & & \\
AS & 0.62069 & 0.57627 & 0.00000 & & \\
CG & 0.09530 & 0.08078 & 0.52475 & 0.00000 & 0.00000 \\
WB & 0.25616 & 0.23782 & 0.52530 & 0.21148 & 0.22571 \\
BR & 0.13793 & 0.11272 & 0.50778 & 0.12862 & 0.00000 \\
UP & 0.24249 & 0.21837 & 0.46772 & 0.20925 & 0.26580 \\
\hline
\end{tabular}

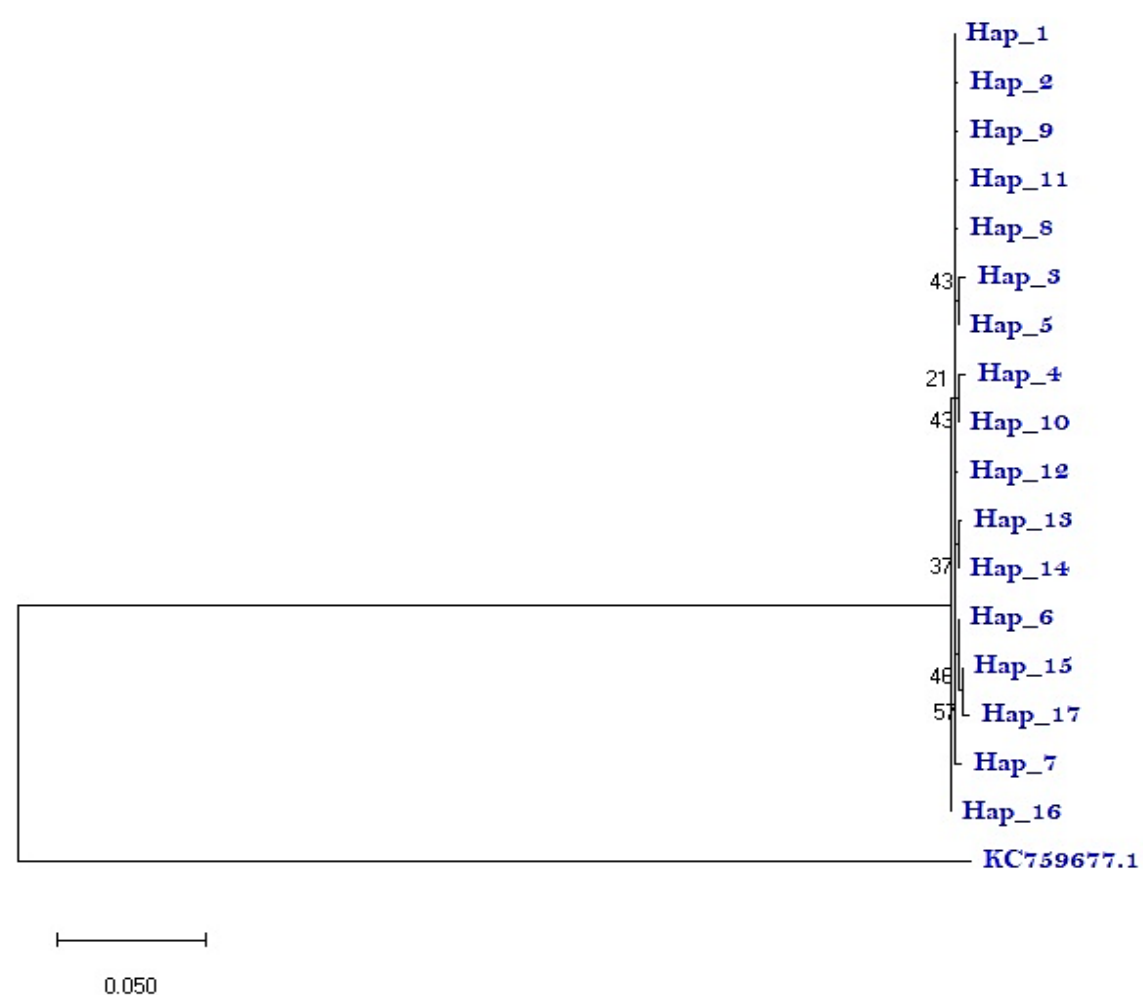

Figure 4. Phylogenetic tree of Clarias magur haplotypes based on Maximum Likelihood method based (Hasegawa-Kishino-Yano model, 1000 bootstraps with the highest log likelihood -1697.97).

the Tajima's D and Fu's Fs values were negative but statistically non-significant. In the present study raggedness index (Table 1 ) under the demographic expansion model for each population was calculated and found to be non-significant indicating that data has relatively good fit to a model of population expansion.

\section{Discussion}

Survival chances of individuals and evolutionary ability of a population rely on maintenance of genetic diversity (Keller and Waller, 2002; Frankham, 2005; Höglund, 2009). Though association between genetic diversity and population health is obvious (Spielman et al., 2004; Höglund, 2009) there are examples of long term existence of populations even though low genetic diversity (Nichols et al., 2001; Johnson et al., 2009). Further, events like gene flow, impact of mutation, migration, selection and genetic drift to draw the management practices and genetic improvement programs depend on population genetic characterization of the natural populations. The goal of the present study was to generate information on genetic diversity and genetic divergence of magur populations. The mitochondrial DNA markers were widely employed to examine population genetic variation and stock characterization (Oleksiak, 2010).

Here the order of composition of bases $A>T>C>G$ observed is in accordance with other fish species (Guo et al., 2003; Sahoo et al., 2019). Further it was observed 
that the sequences of magur $C R$ were $A+T$ rich as observed in other fishes (Johns and Avise, 1998). As reported in other fish species the nucleotide ' $G$ ' was least represented (Bej et al., 2012, Swain et al., 2014; Sahoo et al., 2018). In total, 17 haplotypes were observed, and the number of haplotypes ranged from 2 to 6. Haplotype 1 (Hap01) was shared among all the magur populations suggesting the ancestral haplotype. The seed for magur aquaculture comes from hatcheries as well as natural resources. The sharing of haplotype here might be due to common ancestral origin and subsequent gene flow among populations (Das et al., 2017). Of 17 haplotypes exhibited, 15 are population specific and not shared by other populations. High percentages $(88.2 \%)$ of population specific haplotypes indicated that dispersal among magur individuals is restricted (Chenoweth et al., 1998). Further, exhibition of high number of private haplotypes might be due to independent origin of haplotypes through mutation (Sahoo et al., 2018) and could be used as population specific marker for stock identification. The overall haplotype diversity and nucleotide diversity for seven magur populations were 0.652 and 0.00129, respectively, showing moderate haplotype and low nucleotide diversity. Similar level of genetic diversity was reported earlier for Indian magur populations (Khedkar et al., 2016). The observed $\mathrm{Hd}$ and $\mathrm{Pi}$ in the present study is within the range observed in other freshwater fishes (Habib et al., 2012, $\mathrm{Hd}=0.876$ and $\mathrm{Pi}=0.0843$ ). It is believed that, fishes of the genus Clarias have introduced into India during Eocene period following migration of Indo-Malayan through IndoBrahma River, flowing westward from Assam in the North-East to the present-day Arabian Sea (Daniel, 2001) demonstrating common origin of this species. Low nucleotide diversity observed here might be due to founder effect from different colonization events as well as anthropogenic activities (Khedkar et al., 2016). Further, possibility of population bottleneck due to habitat reduction, reduced availability of resources might have resulted in significant decrease in genetic diversity (Craul et al., 2009; Goossens et al., 2006; Olivieri et al., 2008; Quemere et al., 2009; Sousa et al., 2009). Similar genetic diversity patterns from mtDNA studies have been reported to be associated with parameters such as effective population size and/or selection effects for both nuclear and mitochondrial loci and genomes (Brito, 2007; Burg and Croxall, 2001). High/moderate haplotype diversity and low nucleotide diversity as evidenced in magur populations might be due to the rapid expansion and population growth after a period of low effective population leading to the retention of new mutations (Avise et al., 1984; Rogers and Harpending, 1992). It is a well-known fact that large population size could maintain high haplotype diversity within a population (Nei, 1987; Ma et al., 2010).

The AMOVA analysis for mitochondrial D-loop revealed that $34.01 \%$ variation was due to among populations and $65.99 \%$ was due to within population variation. Within and among population variation for non-migratory fish species reported to be $67.6 \%$ and $32.4 \%$, respectively (Vrijenhoek, 1998) e.g. Labeo fibmbriatus (Swain et al., 2014, 53.76\% and 47.36\%), Catla catla (Behera et al., 2018, 71.65\% and 38.73\%) and Labeo gonius (Behera et al., 2017, 69.47\% and 30.53\%). In the present investigation, the within and among genetic variation is within the range reported for nonmigratory fishes. Significant genetic differentiation (FST 0.01383 to 0.62069 ) among all population pair was observed. Similar results were also reported by Khedkar et al. (2016, Fst 0.06641 to 0.94301). In comparison to estuarine and marine inhabiting fish species freshwater fish species tend to exhibit higher levels of genetic differentiation and population subdivision (Gyllensten, 1985; Ward et al., 1994). Significant genetic differentiation was observed among all magur population pairs and pairwise Fst ranged from 0.01383 to 0.62069 . Similar results were reported for magur in previous studies using microsatellite markers (Mohindra et al., 2012; Jousy et al., 2017). Significant genetic differentiation in the present investigation might be due to restricted gene flow between population pair, wide spread geographical distribution and presence of unique haplotypes (Behera et al., 2017). Additionally, study samples were collected from sampling sites with wide geographic locations, no connectivity and restricted gene flow between the populations may be the possible reasons to make magur populations highly genetically differentiated. Further, this type of genetic clustering patterns may be correlated with the geographical locations of sampling sites. The results of phylogenetics analysis of magur haplotypes revealed monophyly of magur haplotypes in the present study. This might be due to the common ancestral origin of magur populations in India.

\section{Conclusion}

In commercially important aquaculture species, population genetic structure analysis is crucial for optimization of a genetic management strategy or genetic improvement programme. Our study revealed low genetic diversity and significant genetic differentiation observed among magur populations. The information generated in the present study would be very much essential in the management, conservation, and stock improvement programme particularly for a commercially exploited species like $C$. magur in India.

\section{Acknowledgement}

The authors are thankful to the Director, ICARCentral Institute of Freshwater Aquaculture for providing the laboratory facilities. Further, the help rendered by Dr. Ramesh Rathod of RRC Vijayawada of ICAR-CIFA is duly acknowledged. 


\section{References}

Avise, J. C., Neigel, J. E., \& Arnold, J. (1984). Demographic influences on mitochondrial DNA lineage survivorship in animal populations. Journal of Molecular Evolution, 20(2), 99-105.

Avise, J.C. (1986). Mitochondrial DNA and the evolutionary genetics of higher animals. Philosophical Transactions of the Royal Society of London. Series B, Biological Sciences, 312(1154), 325-342. https://doi.org/10.1098/rstb.1986.0011.

Banerjee, B., Koner, D., Hasan, R., Bhattacharya, S., \& Saha, N. (2019). Transcriptome analysis reveals novel insights in air-breathing magur catfish (Clarias magur) in response to high environmental ammonia. Gene, 703, 35-49. https://doi.org/10.1016/j.gene.2019.04.009

Behera, B.K., Baisvar, V.S., Rout, A.K., Pakrashi, S., Kumari, K., Panda, D., Das, P., Parida, P.K., Meena, D.K., Bhakta. D., Das, B.K., \& Jena J.K. (2017). The population structure and genetic divergence of Labeo gonius (Hamilton, 1822) analysed through mitochondrial DNA cytochrome $b$ gene for conservation in Indian waters. Mitochondrial DNA Part A, 29(4),543-551. https://doi.org/10.1080/24701394.2017.1320992

Behera, B. K., Kunal, S. P., Baisvar, V. S., Meena, D. K., Panda, D., Pakrashi, S., Paria, P., Das, P., Debnath, D., Parida, P. K., Das, B. K. \& Jena, J. K. (2018). Genetic variation in wild and hatchery population of Catla catla (Hamilton, 1822) analyzed through mtDNA cytochrome $b$ region. Mitochondrial DNA Part A, 29(1), 126-131. http://dx.doi.org/10.1080/24701394.2016.1253072.

Brito, P.H. (2007). Contrasting patterns of mitochondrial and microsatellite genetic structure among western European populations of Tawny Owls (Strix aluco). Molecular Ecology, 16, 3423-37.

https://doi.org/10.1111/j.1365-294X.2007.03401.x

Burg, T.M., \& Croxall, J.P. (2001). Global relationships among black-browed and grey-headed albatrosses: Analysis of population structure using mitochondrial DNA and microsatellites. Molecular Ecology, 10, 2647-60. https://doi.org/10.1046/j.0962-1083.2001.01392.x

Chan, J., Li, W., Hu, X., Liu, Y., \& Xu, Q. (2016). Genetic diversity and population structure analysis of Qinghai-Tibetan plateau schizothoracine fish (Gymnocypris dobula) based on mtDNA D-loop sequences. Biochemical Systematics and Ecology, 69,152-160. https://doi.org/10.1016/j.bse.2016.09.004.

Chenoweth, S.F., Hughes, J.M., Keenan, C.P., \& Lavery, S. (1998). Concordance between dispersal and mitochondrial gene flow: isolation by distance in a tropical teleost, Lates calcarifer (Australian barramundi). Heredity, 80, 187-197. https://doi.org/10.1046/j.13652540.1998.00292.x

Cherry, J. L., \& Wakeley, J. (2003). A diffusion approximation for selection and drift in a subdivided population. Genetics, 163(1), 421-428.

Craul, M., Chikhi, L., Sousa, V., Olivieri, G., Rabesandratana, A., Zimmermann, E., \& Radespiel, U. (2009). Influence of forest fragmentation on an endangered large-bodied lemur in north western Madagascar. Biological Conservation, 142, 2861-71. https://doi.org/10.1016/j.biocon.2009.05.026.

Das, S.P., Swain, S., Jena, J.K., \& Das, P. (2017). Genetic diversity and population structure of Cirrhinus mrigala revealed by mitochondrial ATPase 6 gene. Mitochondrial DNA Part A, 29(4),495-500.

https://doi.org/10.1080/24701394.2017.1310852

Excoffier, L, \& Lischer, H.E. (2010). Arlequin suite ver 3.5: a new series of programs to perform population genetics analyses under Linux and Windows. Molecular Ecology Resources, 10,564-567. https://doi.org/10.1111/j.17550998.2010.02847.x

Ferguson, A.J.B.T., Taggart, J.B., Prodöhl, P.A., McMeel, O., Thompson, C., Stone, C., Mcginnity, P., \& Hynes, R.A. (1995). The application of molecular markers to the study and conservation of fish populations, with special reference to Salmo. Journal of Fish Biology, 47,103-126. https://doi.org/10.1111/j.1095-8649.1995.tb06048.x

Ferraris, C.J. (2007). Checklist of catfishes, recent and fossil (Osteichthyes: Siluriformes), and catalogue of siluriform primary types. Auckland, New Zealand: Magnolia Press. p 1-628

Fleury, E., Huvet, A., Lelong, C., de Lorgeril, J., Boulo, V., Gueguen, Y., Bachere, E., Tanguy, A., Moraga, D., \& Fabioux, C. (2009). Generation and analysis of a 29,745 unique expressed sequence tags from the Pacific oyster (Crassostrea gigas) assembled into a publicly accessible database: The GigasDatabase. BMC Genomics, 10, 341. https://doi.org/10.1186/1471-2164-10-341

Frankham, R. (2005). Genetics and extinction. Biological Conservation, 126, 131-140. https://doi.org/10.1016/j.biocon.2005.05.002.

Fu, Y. X. (1997). Statistical tests of neutrality of mutations against population growth, hitchhiking and background selection. Genetics, 147(2), 915-925.

Galtier, N., Enard, D., Radondy, Y., Bazin, E., \& Belkhir, K. (2006). Mutation hot spots in mammalian mitochondrial DNA. Genome Research, 16,215-222. https://doi.org/10.1101/gr.4305906

Gong, J., Zhao, R., Deng, J., Zhao, Y., Zuo, J., Huang, L., \& Jing, M. (2018). Genetic diversity and population structure of penis fish (Urechis unicinctus) based on mitochondrial and nuclear gene markers. Mitochondrial DNA Part A. 18. https://doi.org/10.1080/24701394.2018.1444039.

Goossens, B., Chikhi, L., Ancrenaz, M., Lackman-Ancrenaz, I., Andau, P., \& Bruford, M.W.. (2006). Genetic signature of anthropogenic population collapse in orangutans. PLOS Biology, 4,285-91.

https://doi.org/10.1371/journal.pbio.0040025.

Guo, X., Liu, S., \& Liu, Y. (2003). Comparative analysis of the mitochondrial DNA control region in cyprinids with different ploidy level. Aquaculture, 224,25-38. https://doi.org/10.1016/S0044-8486(03)00168-6

Gyllensten U. (1985). The genetic structure of fish: Differences in the intra-specific distribution of biochemical genetic variation between marine, anadromous, and freshwater species. Journal of Fish Biology, 26, 691-9. https://doi.org/10.1111/j.1095-8649.1985.tb04309.x.

Habib, M., Lakra, W.S., Mohindra, V., Lal, K.K., Punia, P., Singh, R.K., \& Khan, A.A. (2012). Assessment of ATPase 8 and ATPase $6 \mathrm{mtDNA}$ sequences in genetic diversity studies of Channa marulius (Channidae: Perciformes). Proceedings of National Academy of Science, India Section B Biological Sciences, 82,497-501. https://doi.org/10.1007/s40011-012-0061-x

Hall, T.A. (1999). BioEdit: a user-friendly biological sequence alignment editor and analysis program for Windows 95/98/NT. In Nucleic acids symposium series. 41, 95-98. 
Han, H.S., Nam, B.H., Kang, J.H., Kim, Y.K., Jee, Y.J., Hur, Y.B., \&Yoon, M. (2012). Genetic variation in wild and cultured populations of the sea squirt Halocynthia roretzi inferred from microsatellite DNA analysis. Fisheries and Aquatic Sciences, 15,151-155.

https://doi.org/10.5657/FAS.2012.0151.

Harpending, H. C. (1994). Signature of ancient population growth in a low-resolution mitochondrial DNA mismatch distribution. Human Biology, 591-600.

Hoban, S., Kelley, J. L., Lotterhos, K. E., Antolin, M. F., Bradburd, G., Lowry, D. B., Poss, M. L., Reed, L. K., Storfer, A. \& Whitlock, M. C. (2016). Finding the genomic basis of local adaptation: pitfalls, practical solutions, and future directions. The American Naturalist, 188(4), 379397.

Höglund, J. (2009). Evolutionary conservation genetics. Oxford University Press.

Hong, S.E., Kim, J.K., Yu, J.N., Kim, K.Y., Lee, C.I., Hong, K.E., Young, P.K., \& Yoon, M. (2012). Genetic variation in the Asian shore crab Hemigrapsus sanguineus in Korean coastal waters as inferred from mitochondrial DNA sequences. Fisheries and Aquatic Sciences, 15,49-56. https://doi.org/10.1080/19768354.2011.604939

Johns, G.C., \& Avise, J.C. (1998). A comparative summary of genetic distances in the vertebrates from the mitochondrial cytochrome $\mathrm{b}$ gene. Molecular Biology and Evolution, 15:1481-1490.

https://doi.org/10.1093/oxfordjournals.molbev.a02587 5

Johnson, J.A., Tingay, R.E., Culver, M., Hailer, F., Clarke, M.L., \& Mindell, D.P. (2009). Long term survival despite low genetic diversity in the critically endangered Madagascar Fish-eagle. Molecular Ecology, 18(1), 54-63. https://doi.org/10.1111/j.1365-294X.2008.04012.x

Jousy, N., Jahageerdar, S., Prasad, J.K., \& Babu, P.G. (2017). Analysis of Genetic Variation in the Natural Populations of Clarias batrachus from India Using Microsatellite Markers. International Journal of Current Microbiology and Applied Sciences, 6(9), 1310-1319. https://doi.org/10.20546/ijcmas.2017.609.158

Jukes, T.H., \&Cantor, C.R. (1969). Evolution of protein molecules. In: Monro HN, editor. Mammalian protein metabolism. 3(21),21-132.

Khedkar, G.D., Tiknaik, A., Kalyankar, A.D., Khedkar, C.D., Ron, T.B., \& Haymer. D. (2016). Genetic structure of populations and conservation issues relating to an endangered catfish, Clarias batrachus, in India. Mitochondrial DNA Part A, 27(2),1181-1187. https://doi.org/10.3109/19401736.2014.945524

Keller, L.F., \& Waller, D.M. (2002). Inbreeding effects in wild populations. Trends in Ecology and Evolution, 17(5),230241. https://doi.org/10.1016/S0169-5347(02)02489-8

Kumar, S,, Stecher, G., Li, M., Knya, C., \& Tamura, K. (2018). MEGA X: molecular evolutionary genetics analysis across computing platforms. Molecular Biology and Evolution, 35(6),1547-1549. https://doi.org/10.1093/molbev/msy096

Langille, B.L., Perr, R., Keefe, D., Barker, O., \& Marshall, H.D. (2016). Mitochondrial population structure and postglacial dispersal of longnose sucker Catostomus catostomus in Labrador, Canada: evidence for multiple refugial origins and limited ongoing gene flow. Journal of Fish Biology, 89, 1378-1392.

https://doi.org/10.1111/jfb.13042.
Liu, Z.J., \& Cordes, J.F. (2004). DNA marker technologies and their applications in aquaculture genetics. Aquaculture, 238,1-37. https://doi.org/10.1016/j.aquaculture.2004.05.027.

Lynch, M., \& Conery, J. S. (2003). The origins of genome complexity. Science, 302(5649), 1401-1404.

Ma, C., Cheng, Q., Zhang, Q., Zhuang, P., \& Zhao, Y. (2010). Genetic variation of Coilia ectenes (Clupeiformes: Engraulidae) revealed by the complete cytochrome $b$ sequences of mitochondrial DNA. Journal of Experimental Marine Biology and Ecology, 385(1-2), 1419. Majhi, S.K., Kumar. S., Maurya, P.K., Mohindra, V., \& Lal, K.K. (2020). Non-invasive method for collection of Clarias magur (Hamilton, 1822) spermatozoa: A novel approach for catfish domestication, aquaculture and conservation. Aquaculture, 519,734737. https://doi.org/10.1016/j.aquaculture.2019.734737.

Melis, R., Vacca, L., Cuccu, D., Mereu, M., Cau, A., Follesa, M.C., $\&$ Cannas, R. (2018). Genetic population structure and phylogeny of the common octopus Octopus vulgaris Cuvier, 1797 in the western Mediterranean Sea through nuclear and mitochondrial markers. Hydrobiologia. 807(1),277-296. . https://doi.org/10.1007/s10750-0173399-5

Mohindra, V., Singh, A., Patangia, R., Tripathi. R.K., Singh, R.K., Sah, R.S., \& Lal. K.K. (2012). Characterization of 27 novel gene-associated SSR markers in Indian catfish, Clarias batrachus (Linnaeus, 1758) and their application in genetic diversity analysis. Molecular Ecology Resources, 12, 1196-1197.

Nei, M., \& Tajima, F. (1983). Maximum likelihood estimation of the number of nucleotide substitutions from restriction sites data. Genetics. 105,207-217.

Nei, M. (1987). Molecular evolutionary genetics. Columbia University Press, New York, U.S.A.pp10-88.

Ng, H.H., \& Kottelat, M. (2008). The identity of Clarias batrachus (Linnaeus, 1758), with the designation of a neotype (Teleostei: Clariidae). Zoological Journal of Linnean Society, 153(4),725-732. https://doi.org/10.1111/j.1096-3642.2008.00391.x.

Nichols, R.A., Bruford, M.W., \& Groombridge, J.J. (2001). Sustaining genetic variation in a small population: evidence from the Mauritius Kestrel. Molecular Ecology, 10,593-602. https://doi.org/10.1046/j.1365294x.2001.01204.x

Oleksiak, M.F. (2010). Genomic approaches with natural fish populations. Journal of Fish Biology, 76,1067-1093. https://doi.org/10.1002/etc.403

Olivieri, G.L., Sousa, V., Chikhi, L., \& Radespiel, U. (2008). From genetic diversity and structure to conservation: Genetic signature of recent population declines in three mouse lemur species (Microcebus spp.). Biological Conservation, 141,1257-71. https://doi.org/10.1016/j.biocon.2008.02.025.

Ovenden, J.R., Leigh, G.M., Blower, D.C., Jones, A.T., Moore, A., Bustamante, C., Buckworth, R.C., Bennet, M.B., \& Dudgeon, C.L. (2016). Can estimates of genetic effective population size contribute to fisheries stock assessments? Journal of Fish Biology, 89,2505-2518. https://doi.org/10.1111/jfb.13129.

Quemere, E., Louis, E., Riberon, A., Chikhi, L., \& Crouau-Roy, B. (2009). Non-invasive conservation genetics of the critically endangered golden-crowned sifaka (Propithecus tattersalli): High diversity and significant 
genetic differentiation over a small range. Conservation Genetics, 11,675-87.

Quilang, J., Wang, S., Li, P., Abernathy, J., Peatman, E., Wang, Y., Wang, L., Shi, Y., Wallace, R., Guo, X., \& Liu, Z. (2007). Generation and analysis of ESTs from the eastern oyster, Crassostrea virginica Gmelin and identification of microsatellite and SNP markers. BMC Genomics, 8,157. https://doi.org/10.1186/1471-2164-8-157.

Reed, D. H. (2004). Extinction risk in fragmented habitats. Animal Conservation, 7(2), 181-191.

Reusch, T. B., Ehlers, A., Hämmerli, A., \& Worm, B. (2005). Ecosystem recovery after climatic extremes enhanced by genotypic diversity. Proceedings of the National Academy of Sciences, 102(8), 2826-2831.

Rogers, A. R., \& Harpending, H. (1992). Population growth makes waves in the distribution of pairwise genetic differences. Molecular Biology and Evolution, 9(3), 552569.

Roy, D., Mitra, A., Biswas, M., Chakraborty, S., Pal, S., \& Homechaudhuri, S. (2019). Early ontogeny of the Asian catfish Magur, Clarias batrachus (Linnaeus, 1758). International Journal of Fisheries and Aquatic Studies. 2019, 7(1): 287-292.

Rozas, J., Ferrer-Mata, A., Sánchez-DelBarrio, J.C., Guirao-Rico, S., Librado, P., Ramos-Onsins, S.E., \& Sánchez-Gracia, A. (2017). DnaSP 6: DNA sequence polymorphism analysis of large data sets. Molecular Biology and Evolution, 34,3299-3302. https://doi.org/10.1093/molbev/msx248.

Sahoo, L., Mohanty, M., Meher, P.K., Murmu, K., Sundaray, J.K., \& Das, P. (2019). Population structure and genetic diversity of hatchery stocks as revealed by combined mtDNA fragment sequences in Indian major carp, Catla catla. Mitochondrial DNA Part A, 30(2), 289-295. https://doi.org/10.1080/24701394.2018.1484120.

Sambrook, J., Fritsch, E.F., \& Maniatis, T. (1989). Molecular cloning: a laboratory manual (No. Ed.2). Cold spring harbor laboratory press.

Schneider, S., \& Excoffier, L. (1999). Estimation of past demographic parameters from the distribution of pairwise differences when the mutation rates vary among sites: application to human mitochondrial DNA. Genetics, 152(3), 1079-1089.

Sousa, V., Penha, F., Pala, I., Chikhi, L., \& Coelho, M. (2009). Conservation genetics of a critically endangered Iberian minnow: Evidence of population decline and extirpations. Animal Conservation, 13,162-71.

https://doi.org/10.1111/j.1469-1795.2009.00317.x.

Souza-Shibatta, L., Kotelok-Diniz, T., Ferreira, D.G., Shibatta, O.A., Sofia, S.H., Assumpcao, L., Pini, S.F.R., Makrakis, S., \& Makrakis, M.C. (2018). Genetic diversity of the endangered Neotropical Cichlid fish (Gymnogeophagus setequedas) in Brazil. Frontiers in Genetics, 9,13. https://doi.org/10.3389/fgene.2018.00013.

Spielman, D., Brook, B.W., \& Frankham, R. (2004). Most species are not driven to extinction before genetic factors impact them. Proceedings of National Academy of Science, USA, 101,15261-15264. https://doi.org/10.1073/pnas.0403809101

Swain, S.K., Bej, D., Das, S.P., Sahoo, L., Jayasankar, P., Das, P.C., \& Das, P. (2014). Genetic variation in Labeo fimbriatus (Cypriniformes: Cyprinidae) populations as revealed by partial cytochrome $b$ sequences of mitochondrial DNA. Mitochondrial DNA part A, 27,11990. https://doi.org/10.3109/19401736.2014.971315.

Tajima, F. (1989). Statistical method for testing the neutral mutation hypothesis by DNA polymorphism. Genetics, 123(3), 585-595.

Tiknaik, A., Khedkar, C., Khedkar, G., Prakash, B., Mamatha, D. M., Sangale, D. \& Kalyankar, A. (2020). Microsatellite Genotyping Corroborated Loss of Genetic Diversity in Clarias batrachus as a Result of Lack of Regulatory Reforms in Aquaculture. Biochemical Genetics, 58:595616. https://doi.org/10.1007/s10528-020-09963-0

Vishwanath, W. 2010. Clarias magur. In: The IUCN Red List of Threatened Species 2010: eT168255A6470089. https://doi.org/10.2305/IUCN.UK.

Vrijenhoek, R.C. 1998. Conservation genetics of freshwater fish. J. Fish Biol. 53,394-412.

Ward, R.D., Woodwark, M., \& Skibinski, D.O.F. (1994). A comparison of genetic diversity levels in marine, freshwater, and anadromous fishes. Journal of Fish Biology, 44,213-32. https://doi.org/10.1111/j.10958649.1994.tb01200.x.

Zhang, Q., Sun, C., Zhu, Y., Xu, N., \& Liu, H. (2020). Genetic diversity and structure of the round-tailed paradise fish (Macropodus ocellatus): Implications for population management. Global Ecology and Conservation, 21, e00876. 